\title{
The mass distribution of coarse particulate organic matter exported from an Alpine headwater stream
}

\author{
J. M. Turowski ${ }^{1,2}$, A. Badoux ${ }^{1}$, K. Bunte ${ }^{3}$, C. Rickli $^{1}$, N. Federspiel ${ }^{1,4}$, and M. Jochner ${ }^{1,5}$ \\ ${ }^{1}$ Swiss Federal Research Institute WSL, Zürcherstrasse 111, 8903 Birmensdorf, Switzerland \\ ${ }^{2}$ Helmholtz Centre Potsdam, GFZ German Research Centre for Geosciences, \\ Telegrafenberg, 14473 Potsdam, Germany \\ ${ }^{3}$ Engineering Research Center, Colorado State University, Fort Collins, CO 80523, USA \\ ${ }^{4}$ CSD Engineers SA, Hessstrasse 27d, 3097 Liebefeld (Berne), Switzerland \\ ${ }^{5}$ Institute of Geography of the University of Berne (GIUB), Hallerstrasse 12, 3012 Berne, Switzerland
}

Correspondence to: J. M. Turowski (turowski@gfz-potsdam.de)

Received: 19 April 2013 - Published in Earth Surf. Dynam. Discuss.: 15 May 2013

Revised: 21 August 2013 - Accepted: 23 August 2013 - Published: 10 September 2013

\begin{abstract}
Coarse particulate organic matter (CPOM) particles span sizes from $1 \mathrm{~mm}$, with a dry mass less than $1 \mathrm{mg}$, to large logs and entire trees, which can have a dry mass of several hundred kilograms. Pieces of different size and mass play different roles in stream environments, from being the prime source of energy in stream ecosystems to macroscopically determining channel morphology and local hydraulics. We show that a single scaling exponent can describe the mass distribution of CPOM heavier than $0.1 \mathrm{~g}$ transported in the Erlenbach, a steep mountain stream in the Swiss pre-Alps. This exponent takes an average value of -1.8 , is independent of discharge and valid for particle masses spanning almost seven orders of magnitude. Similarly, the mass distribution of in-stream large woody debris (LWD) in several Swiss streams can be described by power law scaling distributions, with exponents varying between -1.8 and -2.0 , if all in-stream LWD is considered, and between -1.3 and -1.8 for material locked in log jams. We found similar values for in-stream and transported material in the literature. We had expected that scaling exponents are determined by stream type, vegetation, climate, substrate properties, and the connectivity between channels and hillslopes. However, none of the descriptor variables tested here, including drainage area, channel bed slope and the percentage of forested area, show a strong control on exponent value. Together with a rating curve of CPOM transport rates with discharge, the scaling exponents can be used in the design of measuring strategies and in natural hazard mitigation.
\end{abstract}

\section{Introduction}

Coarse particulate organic matter (CPOM) plays multiple roles in stream systems. Usually defined as pieces of organic matter with a diameter larger than $1 \mathrm{~mm}$ (e.g., Fisher and Likens, 1972, 1973; Cummins, 1974; Webster et al., 1999), it spans the range from leaves, needles and wood fragments to twigs and branches to logs and entire trees. Large woody debris (LWD), at the top of this range, is often defined as having a minimum diameter of $0.1 \mathrm{~m}$ and a minimum length of $1 \mathrm{~m}$ (e.g., Abbe and Montgomery, 2003; Faustini and Jones, 2003; Mao et al., 2008; Wohl and Jaeger, 2009), but others have used minimum lengths of $0.5,1.5$ or $3 \mathrm{~m}$, and various di- ameters (e.g., Hassan et al., 2005; Jackson and Sturm, 2002; Martin and Benda, 2001). Each size group within the wide range of CPOM sizes fulfills different geomorphic and ecological roles (e.g., Harmon et al., 1986). Leaves and twigs and their decay products are consumed by in-stream shredders and suspension feeders. This so-called allochthonous organic matter, which is produced outside of the stream system, enters the channel, for example, as litter fall from adjoining forest. Especially in headwater catchments it is the prime source of energy in stream ecosystems (e.g., Fisher and Likens, 1973; Minshall, 1967). Larger pieces of woody debris change flow hydraulics, and thus have an effect on flow 
velocity and sediment transport rates, which affects habitat and breeding grounds for fish and other aquatic animals (e.g., Abbe and Montgomery, 1996; Bilby and Ward, 1991; Brooks et al., 2004; Keller and Swanson, 1979; MacFarlane and Wohl, 2003; Montgomery and Piégay, 2003). Log jams are often a major element of stream morphology, and floating logs may pose a natural hazard (e.g., Comiti et al., 2006; Curran, 2010; Kraft and Warren, 2003; Manga and Kirchner, 2000; Mao et al., 2008; Mazzorana et al., 2011; Rickenmann, 1997).

Wood budgets are a common tool in geomorphology to assess availability and transport of woody material, but often focus on LWD (e.g., Benda and Sias, 2003; Keller and Swanson, 1979; Martin and Benda, 2001; Reeves et al., 2003). Budgets of smaller organic material are necessary in ecological studies to assess the availability of food in a stream (e.g., Fisher and Likens, 1973; Webster and Meyer, 1997), but typically focus on small streams where LWD rarely moves. Studies investigating the entire size range of transported material, from leaves to logs, are rare. It is currently unclear how the different CPOM size groups, especially LWD and leaf-size fractions, relate to each other. Size distributions have been reported for LWD only, either based on piece diameter or volume of material stored in the stream (Harmon et al., 1986; Hogan, 1987; Jackson and Sturm, 2002; Rickli and Bucher, 2006), or piece length of transported material (MacVicar and Piégay, 2012). Here, we hypothesize that the use of dry mass as a descriptor variable leads to a scaling relation consistently connecting all CPOM size groups transported by a stream, from leaves to large logs. We have measured transport rates and dry masses of CPOM pieces heavier than $0.1 \mathrm{~g}$ moving in the Erlenbach, a headwater stream in the Swiss pre-Alps, using several sampling methods over a large range of discharges. In addition, we collected data on in-stream LWD size distributions for the Erlenbach, and compared it to data from ten other mountain streams in Switzerland (Rickli and Bucher, 2006), and from the literature. We discuss the use of scaling relations in the design of sampling campaigns, data analysis and natural hazard mitigation.

\section{Field site}

The Erlenbach is a small headwater stream located near Einsiedeln in the Swiss pre-Alps (Fig. 1), where scientific observations have been conducted since the late 1960s (Hegg et al., 2006). The channel bed has a mean gradient of around $18 \%$ and drains an area of $0.7 \mathrm{~km}^{2}$ at the main observation site. About $40 \%$ of the total catchment area is forested, with the remaining $60 \%$ consisting of wetland and Alpine meadows. The forest dominantly comprises Norway spruce (Picea abies) and European Silver Fir (Abies alba), intermingled with some Alder (Alnus sp.), and a wide variety of shrubs and ground plants (Schleppi et al., 1999). The Erlenbach is a step-pool channel with high sediment load, which is mainly

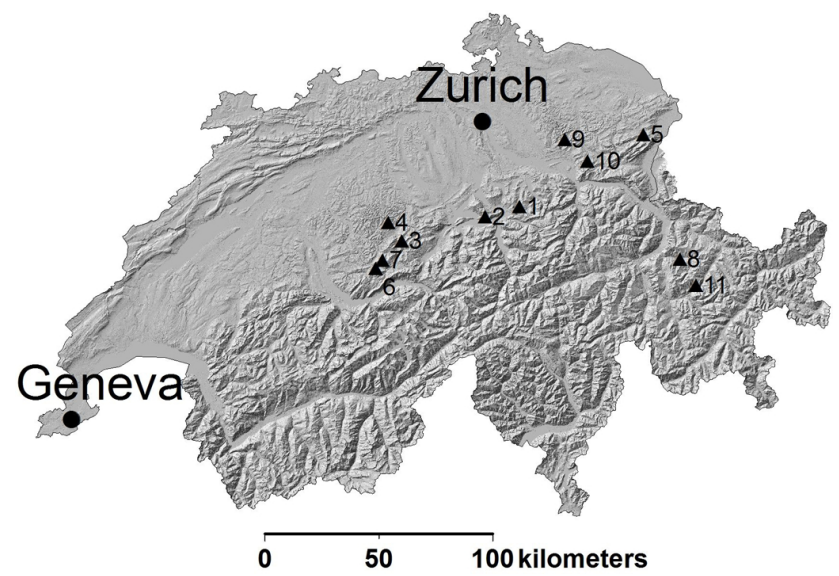

Figure 1. Location map of the Erlenbach (1) and the ten streams studied by Rickli and Bucher (2006) in Switzerland (see also Table 1).

supplied by a series of slow-moving landslides along the channel banks (Schuerch et al., 2006; Turowski et al., 2009; Molnar et al., 2010). There are two discharge gauges located immediately upstream and downstream of a sediment retention basin where automatic basket samplers and indirect bedload sensors for sediment transport measurements are available (Rickenmann et al., 2012; Turowski et al., 2011). Discharge is continuously recorded at $10 \mathrm{~min}$ intervals, and at 1 min intervals during bedload transport events. Unless otherwise stated, we used the $10 \mathrm{~min}$ data of the upper gauge throughout this paper. The mean discharge at the Erlenbach is $39 \mathrm{~L} \mathrm{~s}^{-1}$, and during dry weather it is typically below $10 \mathrm{~L} \mathrm{~s}^{-1}$. Floods, driven mainly by convective summer storms, are common, and stream flow quickly responds to heavy rainfall. The annual return discharge is approximately $2000 \mathrm{~L} \mathrm{~s}^{-1}$. The highest discharge recorded in the last $30 \mathrm{yr}$ occurred on 20 June 2007. At $\sim 11100 \mathrm{~L} \mathrm{~s}^{-1}$ (10 min data), its return frequency is estimated at around $50 \mathrm{yr}$ (Turowski et al., 2009, 2013).

\section{Methods}

Transported CPOM was sampled using three different methods, ensuring the possibility of sampling a wide range of particle sizes and discharges (Fig. 2). At low to intermediate discharges (from 1 to $\sim 1000 \mathrm{~L} \mathrm{~s}^{-1}$, with most samples below $250 \mathrm{~L} \mathrm{~s}^{-1}$ ), when the stream was wadeable, we used bedload traps (Bunte et al., 2004, 2007). Automatic basket samplers were used at higher discharges (from 200 to $1500 \mathrm{~L} \mathrm{~s}^{-1}$, with most samples above $400 \mathrm{~L} \mathrm{~s}^{-1}$ ) (Rickenmann et al., 2012). Two samples were obtained from measuring woody material accumulated in the retention basin after two large floods that occurred in 1995 and 2010 (cf. Turowski et al., 2009, 2013).

Bedload traps are portable samplers installed on metal plates placed on the channel bed. They were specifically 

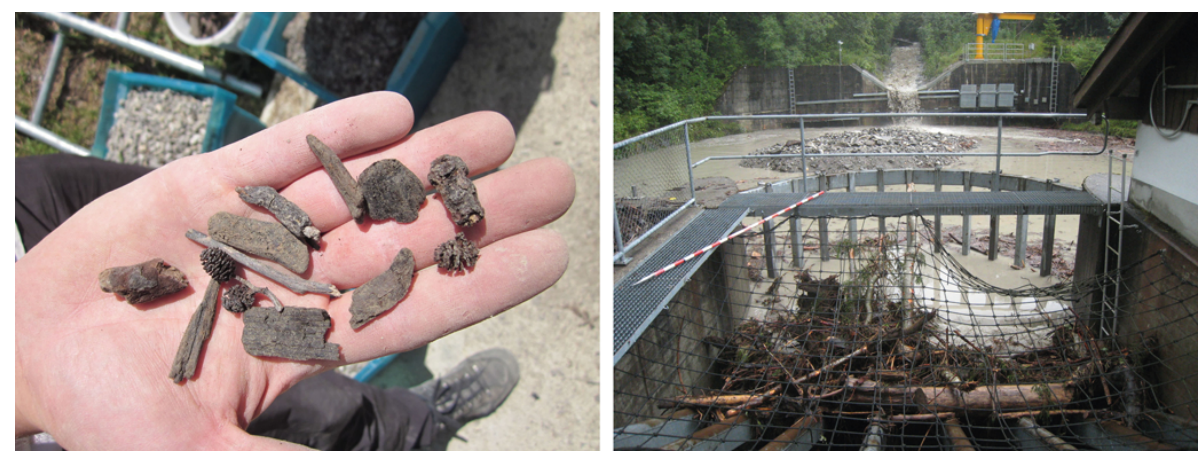

Figure 2. (left panel) Typical CPOM pieces caught in the basket samplers, including twigs, chips of woody material, bark fragments, scales of conifer cones, and alder catkins. The typical dry mass of the pieces shown ranges from a tenth of a gram up to a few grams. (right panel) LWD material caught in the outlet grid of the retention basin in the extreme event from 1 August 2010 (picture taken on the 2 August 2010). The retention basin and the basket samplers can be seen in the background.

designed for obtaining samples of gravel bedload (Bunte et al., 2004, 2007), but are also suitable for sampling CPOM. Bedload traps consist of an aluminium frame, $0.3 \mathrm{~m}$ wide and $0.2 \mathrm{~m}$ high, to which a net $1-2 \mathrm{~m}$ long is attached. Bedload trap samples were obtained from three channel locations across a step-pool unit located $\sim 20 \mathrm{~m}$ upstream of the discharge gauge: at the crown and the foot of a step and at the end of the associated pool. Bedload traps sample the whole flow depth and sampling efficiency is mainly determined by the minimum and maximum size of particles that can be sampled. In the flows the traps were used for, it was possible to sample the largest transported CPOM particles. A single trap was sufficient to cover the entire flow width at the crown and the foot of the step. At the pool exit, two traps were used to sample the flow width of approximately $2.6 \mathrm{~m}$, one located near the thalweg, the other on a submerged gravel bank. The transport rates measured with these two traps were assumed to be representative for unmeasured parts of the channel cross section, in the main flow channel and on the gravel bank, respectively. To obtain transport rates over the whole flow width, we divided the transported mass by trap width and multiplied by the width of the relevant section (i.e., the gravel bank or the main channel), and added the values for both sections. Interpolated transport rates for the whole channel width measured by the two traps at the pool exit were assumed to be representative for the entire channel, as they were similar to transport rates measured at the crown and the foot of the step at similar discharges. The traps used at the Erlenbach have a net opening size of $6 \mathrm{~mm}$. At most discharges, we sampled for 10-20 min. However, the sampling time was adjusted to match the supply rate of material (both bedload and CPOM). At the highest discharges of around $1000 \mathrm{~L} \mathrm{~s}^{-1}$, sampling times were reduced to a few minutes to avoid overfilling of the nets. At the lowest discharges $\left(<10 \mathrm{~L} \mathrm{~s}^{-1}\right)$ sampling times of up to nearly seven hours were needed to collect a sufficient amount of material. Samples were taken in spring 2012 during snowmelt events, and in summer 2012 at higher discharges in rainfall-driven flow events and at baseflow discharges.

The automatic basket samplers consist of metal cubes with $1 \mathrm{~m}$ edges (Rickenmann et al., 2012, see also Fig. 2b). The baskets' walls and floors are made of a metal mesh of square holes with an edge length of $10 \mathrm{~mm}$. Sampling is triggered when thresholds of stage level and indirect bedload sensor activity are exceeded. The entire flow width is sampled at discharges below around $1500 \mathrm{~L} \mathrm{~s}^{-1}$, and the opening size of the baskets is large enough to capture the largest CPOM particle sizes transported in these flows. Sampling efficiency is determined mainly by the lower limit of sampled sizes $(10 \mathrm{~mm})$. Basket samples were taken from May to November of 2009 to 2012 during rainfall-driven floods.

Organic matter from basket and trap samples was separated from clastic material and weighed wet in the field. Subsequently, the samples were oven-dried over $24 \mathrm{~h}$ at $80^{\circ} \mathrm{C}$ in the laboratory, and the dry mass was obtained. For a total of 18 out of 42 basket samples, all pieces of organic matter heavier than about $1 \mathrm{~g}$ were individually weighed and measured. For ten samples taken at lower background discharges with the bedload traps, we individually weighed all pieces heavier than $0.1 \mathrm{~g}$, or all pieces heavier than $0.01 \mathrm{~g}$, if the total number of pieces in the sample was small.

After two large floods, in July 1995 and August 2010 with peak discharges of $\sim 10100 \mathrm{~L} \mathrm{~s}^{-1}$ and $\sim 9300 \mathrm{~L} \mathrm{~s}^{-1}$, respectively (10 min data) (Turowski et al., 2009, 2013, see also Fig. 2b), pieces of woody debris with diameters larger than $0.05 \mathrm{~m}$ were collected from the sediment retention basin, and their lengths and diameters were measured in the field. The measurements were converted to mass assuming a cylindrical shape and a dry wood density of $410 \mathrm{~kg} \mathrm{~m}^{-3}$, which is typical for the Norway spruce (Picea abies) that is common in the catchment. Substantial volumes of LWD have been observed in the retention basin after events that exceeded this discharge, whereas only a few LWD pieces have been found in the retention basin after events with lower peaks. Thus, 


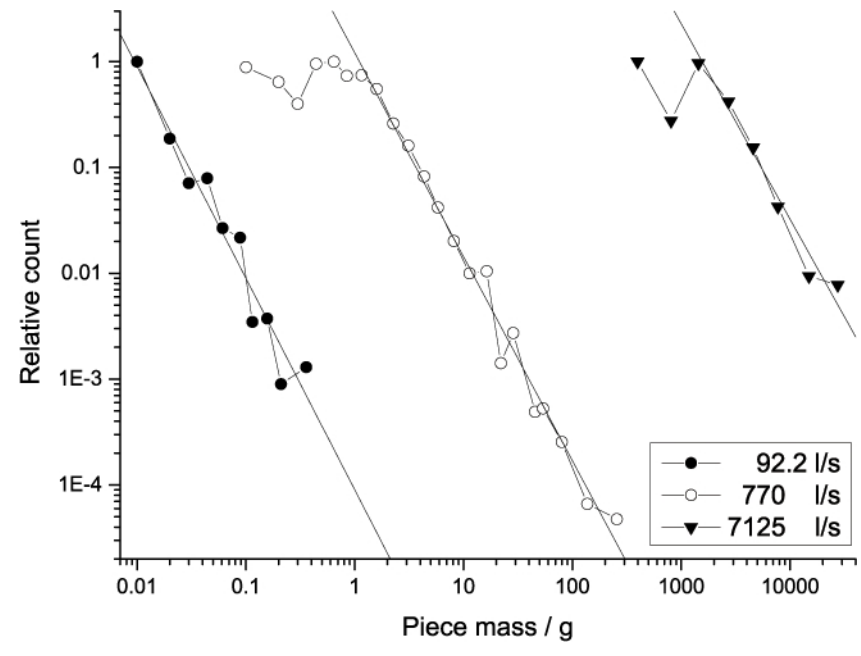

Figure 3. Examples of histograms of CPOM particle masses at three different discharges, spanning two orders of magnitude in discharge and more than six orders of magnitude in particle mass. To reduce the extent of the axes, and to demonstrate the general similarity of the CPOM piece count vs. mass relations, each of the histograms was normalized such that the most common fraction plots at a relative count of one. The sample collected at $92.2 \mathrm{~L} \mathrm{~s}^{-1}$ is typical of those taken with bedload traps, the one at $770 \mathrm{~L} \mathrm{~s}^{-1}$ of those with basket samplers, and the one at $7125 \mathrm{~L} \mathrm{~s}^{-1}$ was collected from the debris basin.

to obtain a representative discharge for the retention basin data points, we assumed that large pieces of wood are dominantly transported at discharges higher than $5000 \mathrm{~L} \mathrm{~s}^{-1}$, using measurements at $1 \mathrm{~min}$ resolution. The $5000 \mathrm{~L} \mathrm{~s}^{-1}$ threshold was exceeded for 20 and $18 \mathrm{~min}$, respectively, during the two events, and accordingly we averaged all discharge measurements exceeding it.

In addition to sampling material transported by the stream, the length and diameter of all woody debris pieces longer than $1 \mathrm{~m}$ (LWD) stored in log jams were recorded in the field. LWD masses were calculated assuming a cylindrical shape and a dry wood density of $410 \mathrm{~kg} \mathrm{~m}^{-3}$.

\section{Results and analysis}

The frequency of occurrence of sampled CPOM particles is tightly related to their masses; the number of CPOM pieces in transport strongly decreased with increasing particle mass. At particle masses greater than a threshold value of $\sim 1 \mathrm{~g}$ for the basket samples and $\sim 3 \mathrm{~kg}$ for the retention basin samples, the relative frequencies of occurrence of masses in the samples plot on a straight line in log-log space (Fig. 3). No such threshold was observed for the bedload trap data because the smaller net size trapped finer particles. The relationships can be described by the equation

$C=k M^{-\alpha}$.

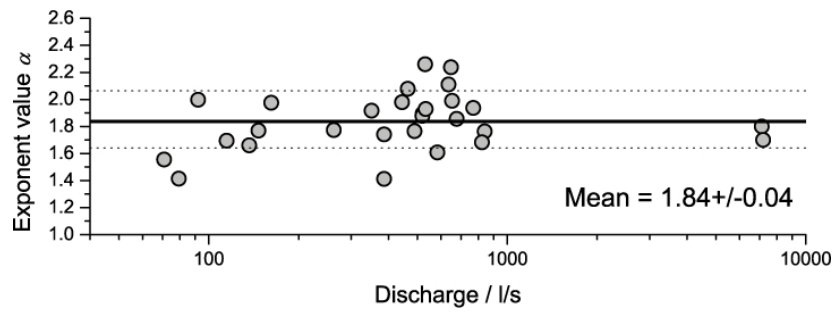

Figure 4. Scaling exponents of the mass distribution as function of discharge for the Erlenbach samples. No trend is visible. The solid line gives the mean value, dotted lines depict one standard deviation around the mean.

Here, $C$ is the relative fraction of CPOM of the respective particle mass $M, k$ is a constant and $\alpha$ is the scaling exponent. The relative fraction is proportional to the measured fraction of CPOM in each mass class, but may be normalized for example by bin width. For each CPOM sample, scaling exponents were obtained by fitting a linear relation to the logtransformed data in the long falling branch. Minimum and maximum values of $\alpha$ were 1.41 and 2.26, respectively, and the mean of 28 samples was $1.84 \pm 0.04$ (range gives standard error of the mean). For all discharges where samples contained enough individual pieces of material to derive a relation between piece numbers and mass, scaling exponents were independent of discharge (Fig. 4).

By dividing total CPOM mass by sampling time, we obtained CPOM transport rates. These show a clear relation with discharge, defined by a straight line in $\log -\log$ space (Fig. 5, grey symbols). However, it needs to be borne in mind that we used different sampling devices with different net sizes (bedload traps: $6 \mathrm{~mm}$; basket samplers: $10 \mathrm{~mm}$; LWD from the retention basin). Below we will show how the scaling relation of Eq. (1) can be used to make the samples comparable.

As long as the scaling exponent $\alpha>1$, the total mass $M_{\text {tot }}$ of the sample above a minimum mass $M_{\min }$ can be obtained by using the integral

$M_{\mathrm{tot}}=\int_{M_{\min }}^{\infty} k M^{-\alpha} \mathrm{d} M=\frac{k M_{\mathrm{min}}^{1-\alpha}}{\alpha-1}$.

The ratio between the total mass $M_{1, \text { tot }}$ larger than a threshold mass $M_{1, \min }$, and the total mass $M_{2, \text { tot }}$ larger than a threshold mass $M_{2, \min }$ can thus be written as

$\frac{M_{1, \text { tot }}}{M_{2, \text { tot }}}=\left(\frac{M_{1, \min }}{M_{2, \min }}\right)^{1-\alpha}$.

To be able to compare the samples taken with bedload traps and basket samplers, we estimated the minimal particle mass that is sampled representatively by the baskets at $1 \mathrm{~g}$. The lack of a further increase in relative counts for smaller particles indicates that not all material of smaller masses was 
Table 1. Characteristics of the Swiss streams and scaling exponents (see also Fig. 1).

\begin{tabular}{|c|c|c|c|c|c|c|c|c|c|c|}
\hline & Stream & $\begin{array}{l}\text { Community, } \\
\text { Canton }^{1}\end{array}$ & $\begin{array}{l}\text { Drainage } \\
\text { area } \\
\left(\mathrm{km}^{2}\right)\end{array}$ & $\begin{array}{c}\% \\
\text { forested }\end{array}$ & $\begin{array}{r}\text { Mean } \\
\text { elevation } \\
\text { (m a.s.1.) }\end{array}$ & $\begin{array}{c}\text { Channel } \\
\text { bed slope }\end{array}$ & $\begin{array}{r}\text { Mean } \\
\text { channel } \\
\text { width }(\mathrm{m})\end{array}$ & $\begin{array}{l}\text { Scaling } \\
\text { exponent } \\
\text { (transport) }\end{array}$ & $\begin{array}{l}\text { Scaling } \\
\text { exponent } \\
\text { (in stream) }^{2}\end{array}$ & $\begin{array}{l}\text { Scaling } \\
\text { exponent } \\
(\log \text { jams })^{2}\end{array}$ \\
\hline 1 & Erlenbach & Brunni, SZ & 0.7 & 40 & 1347 & 0.105 & 4.0 & \multirow[t]{11}{*}{1.84} & N.A. ${ }^{3}$ & $1.26(79)$ \\
\hline 2 & Brüggenwaldbach & Gersau, SZ & 0.81 & 33 & 804 & 0.341 & 8.7 & & $2.04(472)$ & $0.93(14)$ \\
\hline 3 & Steinibach & Flühli, LU & 1.49 & 17 & 1160 & 0.164 & 8.8 & & $1.89(679)$ & $1.75(106)$ \\
\hline 4 & Seeblibach & Romoos, LU & 1.16 & 47 & 950 & 0.104 & 6.3 & & $1.85(781)$ & $1.68(173)$ \\
\hline 5 & Ibach & Weissbad, AI & 1.64 & 26 & 880 & 0.070 & 8.3 & & $1.90(485)$ & $1.64(112)$ \\
\hline 6 & Büetschligraben & Schangnau, BE & 2.24 & 18 & 1040 & 0.155 & 10.9 & & $1.86(567)$ & $1.64(33)$ \\
\hline 7 & Steiglebach & Marbach, LU & 3.02 & 40 & 1180 & 0.074 & 10.2 & & $1.85(572)$ & $1.39(177)$ \\
\hline 8 & Grossbach & Molinis, GR & 2.40 & 38 & 1190 & 0.278 & 11.2 & & $1.88(687)$ & $0.97(8)$ \\
\hline 9 & Chreuelbach & Goldingen, SG & 0.88 & 65 & 920 & 0.132 & 6.9 & & $1.78(857)$ & $1.69(98)$ \\
\hline 10 & Geissbach & Ebnat-Kappel, SG & 1.63 & 45 & 1080 & 0.095 & 9.5 & & $1.84(749)$ & $1.52(104)$ \\
\hline \multirow[t]{6}{*}{11} & Ursprung & Wiesen, GR & 1.33 & 50 & 1610 & 0.089 & 8.9 & & $1.87(879)$ & $1.71(252)$ \\
\hline & Literature data & Source & & & & & & & & \\
\hline & Ain River, France & MacVicar and Piégay (2012) & 3630 & & & 0.0015 & 65 & \multirow[t]{4}{*}{1.8} & & \\
\hline & small, British Columbia & Hogan (1987) & 3.9 & & & 0.024 & 18.8 & & 1.72 & \\
\hline & medium, British Columbia & Hogan (1987) & 6.9 & & & 0.013 & 20.2 & & 1.61 & \\
\hline & large, British Columbia & Hogan (1987) & 20.2 & & & 0.007 & 29.3 & & 1.90 & \\
\hline
\end{tabular}

${ }^{1}$ See Fig. $1 ;{ }^{2}$ the number of data points used in the fit is given in brackets; ${ }^{3}$ in the Erlenbach, only material in log jams was surveyed.

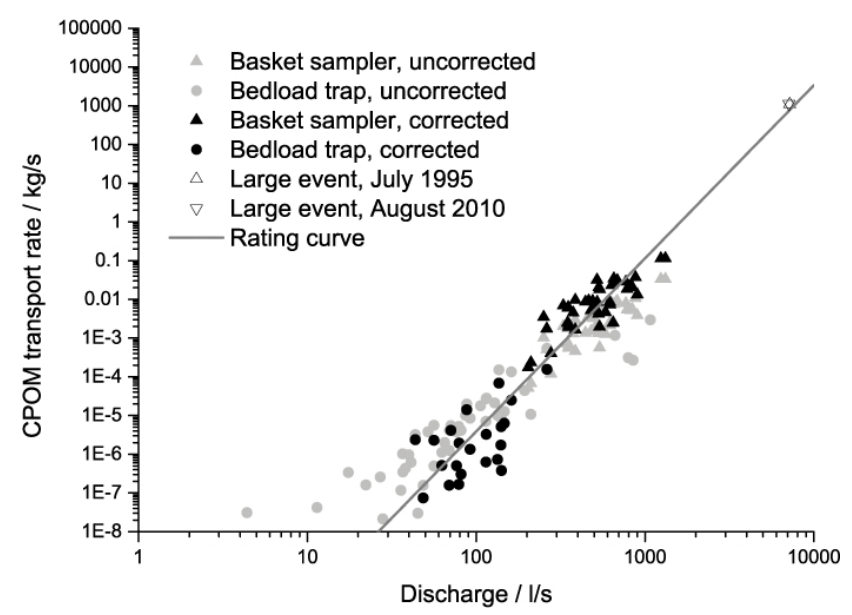

Figure 5. CPOM transport rates as a functions of discharge. Both the untreated data (light grey) and the values corrected for transport rates of all particles heavier than $0.1 \mathrm{~g}$ (black) are shown. The rating curve is of the form $Q_{\mathrm{CPOM}}=a Q^{b}$, with $a=4.42 \times 10^{-15}$ and $b=$ $4.47 \pm 0.21$, with an $R$ value of 0.94 . The two data points from the large events (open triangles) plot nearly at the same location. They were not used in the regression to obtain the rating curve.

sampled (see Fig. 3). Particles lighter than $1 \mathrm{~g}$ were omitted from the samples, and the remainder was used for further analysis. For basket samples where the mass distribution was not measured, we used the average fraction of mass contributed by $1 \mathrm{~g}$ particles to the total mass $(=0.48)$ from the basket samples where it was measured. This value was multiplied with the total measured CPOM mass. For each basket sample, the total mass above $0.1 \mathrm{~g}$ was then calculated using Eq. (3). For the bedload trap samples, we only used samples for which the mass distribution was measured and which included individual pieces heavier than $0.1 \mathrm{~g}$.
The corrected samples were plotted against discharge to obtain a rating curve (Fig. 5, black symbols). The rating exponent of 4.47 was obtained by fitting a linear relationship to the log-transformed data. The data points from the two extreme events were not included in the fit. They are the least reliable data points, because only particles heavier than about $3 \mathrm{~kg}$ (dry mass) were sampled representatively, and the measured masses of 237 (1995 event) and $219 \mathrm{~kg}$ (2010 event) were subsequently extrapolated down to piece masses of $0.1 \mathrm{~g}$ using the average scaling exponent of 1.84 (Fig. 4). The resulting points plot close to the rating curve derived from the trap and basket measurements and confirm the validity of the CPOM transport rating relation at high discharges (Fig. 5).

In nine log jams along the Erlenbach channel, we measured a total of 79 pieces of LWD. The size distribution of this material likewise decreased with particle mass (Fig. 6), although with a value of 1.26 the scaling exponent was lower than observed for transported material. Scaling exponents similar to those from the Erlenbach were also obtained from 6700 wood pieces measured in ten other Swiss mountain streams (Rickli and Bucher, 2006; see Table 1). Power function scaling exponents ranged within 1.78 and 2.04 for all wood pieces in the channel and within 1.39 and 1.75 for those locked in log jams (Fig. 7) (the two extraordinary low values at the Brüggenwaldbach and the Grossbach were derived from small sample sizes and are therefore unreliable). Scaling exponents appeared unrelated to basin area size, stream width and gradient, and the percent forested area (Fig. 8). 


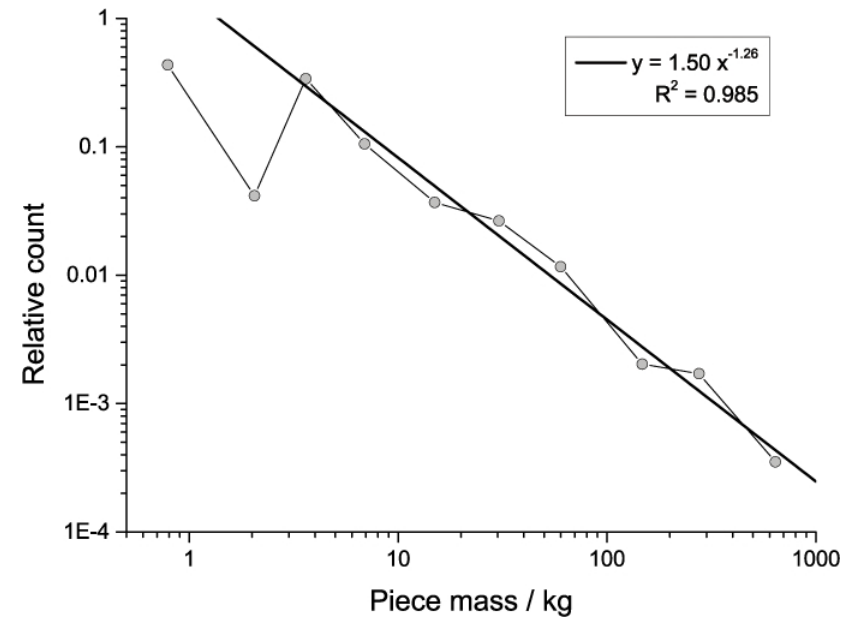

Figure 6. Scaling distributions of piece mass for LWD locked in log jams in the Erlenbach channel.

\section{Discussion}

\subsection{Masses of CPOM input and piece break down}

Various processes in the stream work together to produce the observed mass distribution of CPOM particles from the original mass distribution of organic material supplied to the stream. Coarse particulate organic matter enters the stream either as litter fall directly from the trees or blown in by wind, or via the stream banks either as material advected into the channel by landslides and snow creep, or flushed into it by overland flow (cf. Benda and Sias, 2003; Fisher and Likens, 1973; Hassan et al., 2005; Harmon et al., 1986). Litter typically comprises leaves with dry masses below $0.1 \mathrm{~g}$ and twigs with masses smaller than about $5 \mathrm{~g}$. Larger material, often entire trees, can enter the channel due to wind throw or by riding on top of landslides. A number of slowmoving landslide complexes have been identified along the banks of the Erlenbach, causing efficient channel-hillslope connectivity (Schuerch et al., 2006). Trees, tree trunks and large branches are abundant in the Erlenbach channel and along the banks. Thus, based on preliminary data from litter traps installed above the stream channel and from field observations, we can assume that the input distribution of CPOM masses is strongly bimodal, with one peak lying within 0.1 to $1 \mathrm{~g}$ (leaves and twigs), and one at $>100 \mathrm{~kg}$ (whole trees). The mass distribution of the material flushed out of the stream therefore does not correspond to the input distribution, and in-stream processes must break down larger material while it resides in the channel. These processes can be broadly divided into physical, chemical and biological processes (although these may interact) (Harmon et al., 1986; Merten et al., 2013; Webster et al., 1999). The physical processes include breakage and detachment of pieces by fluid stressing, grinding of woody debris by gravel bedload, woodwood interaction (for example a floating log impacting sta-
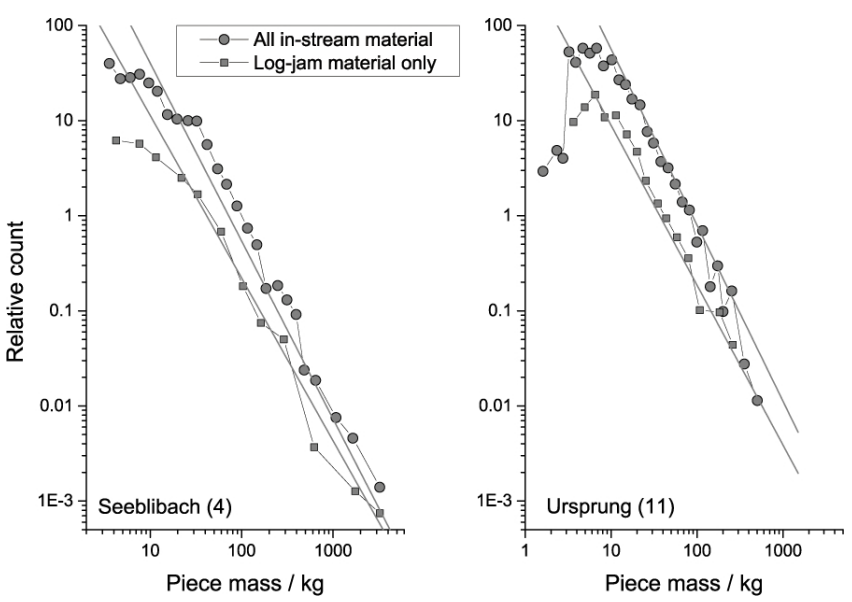

Figure 7. Scaling distributions of piece mass for LWD in the Seeblibach (4) and Ursprung (11) (see Table 1), as examples for distributions observed in the Swiss mountain streams (Rickli and Bucher, 2006). Distributions both for material locked in log jams (square symbols) and for all material (circles) stored in the channel are shown.

tionary material), or the break-up of log jams (Harmon et al., 1986). In addition, wetting/drying cycles and possibly freezing/thawing may lead to swelling and cracking of wood. Parts of woody material can be dissolved in water and carried out in solution (e.g., Yoshimura et al., 2010). This loss of material may destabilize the structure of the debris and make it more prone to physical erosion. Finally, bacteria and fungi colonize dead wood and decompose it, while animals, for example fresh-water invertebrates or certain types of insects such as Plecoptera larvae, may attack CPOM pieces to obtain food or to create shelter (e.g., Webster and Benfield, 1986; Montemarano et al., 2007). As pointed out by Hassan et al. (2005), little is known about the relative importance of different wood depletion processes. Merten et al. (2013) found that physical breakage was responsible for a mass loss of around $7.3 \%$ in LWD, while decay processes contributed around $1.9 \%$ in streams in northern Minnesota, USA. However, it is currently unclear how these results transfer to other regions. In addition, it is not known what piece sizes are produced by the various deterioration processes, how fluvial transport affects the CPOM/LWD size distribution, and how exactly the different processes play together to produce the observed output mass distribution. Finally, it would be interesting to compare the mass distribution of in-stream CPOM to the distributions of branch mass in living trees. However, although the necessary data must have been recorded for studies of tree allometry (e.g., Bertram, 1989: Dassot et al., 2012), we were unable to obtain such data, or to find relevant accounts in the literature. 

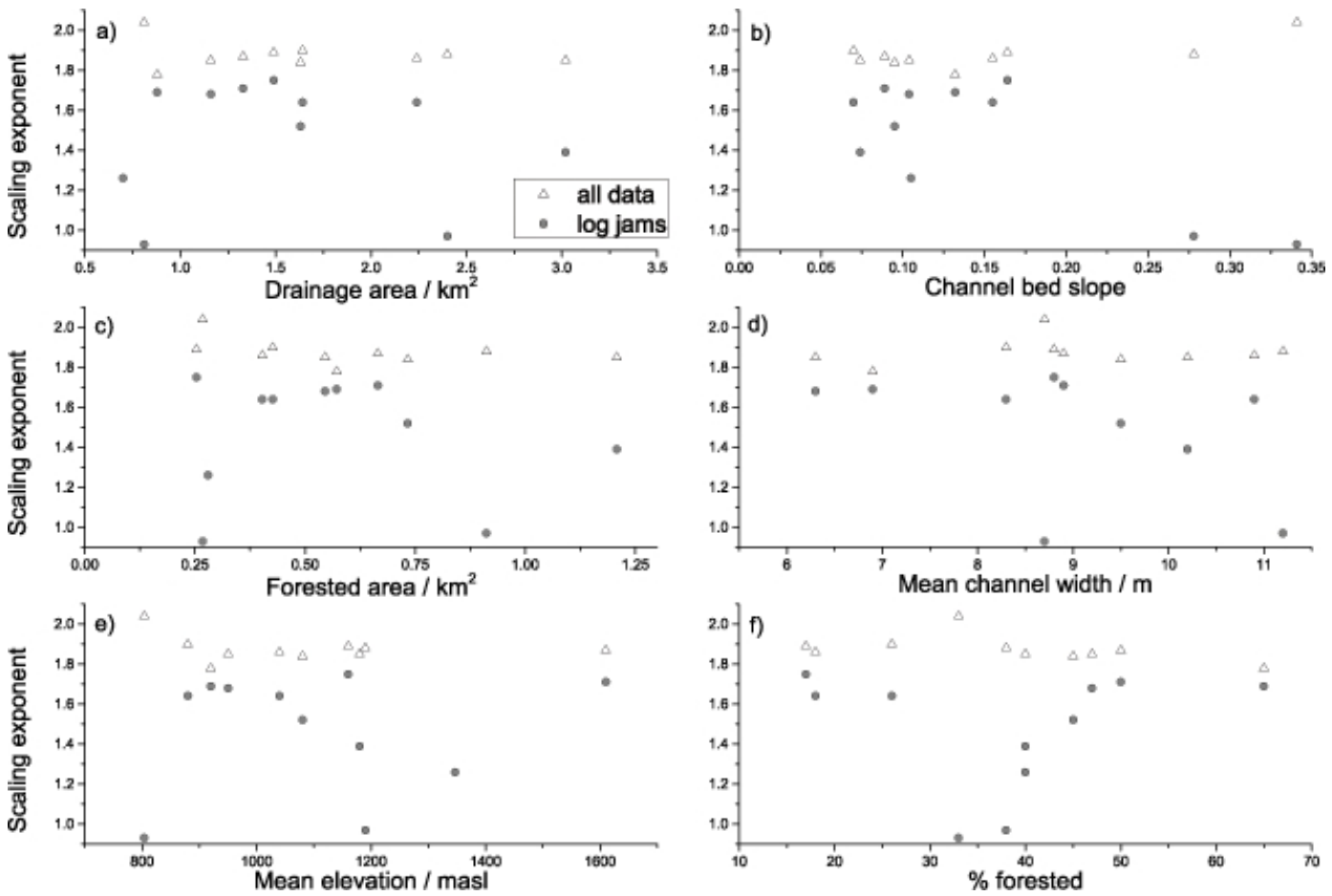

Figure 8. Scaling exponents of eleven Swiss mountain streams (Table 1) as functions of (a) drainage area, (b) channel bed slope, (c) forested area, (d) mean channel width, (e) mean elevation above sea level, and (f) percent fraction of the catchment covered by forest. Note that the two lowest scaling exponents for log jam material at 0.93 and 0.97 , corresponding to the Brüggenwaldbach and Grossbach (Table 1), are based on a small number of measurement and are probably spurious. No strong correlations or trends are obvious.

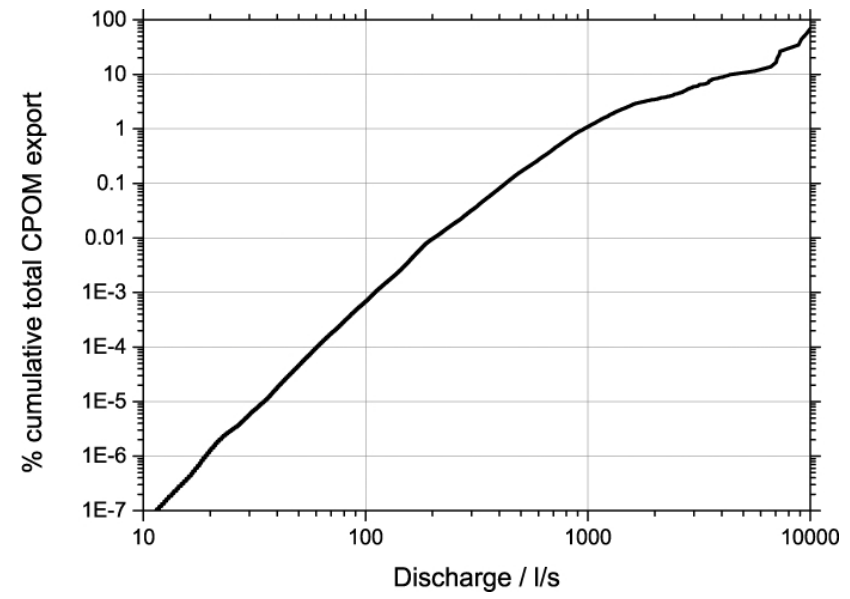

Figure 9. Percentage of the total cumulative CPOM export from the catchment as a function of discharge, obtained by integrating the rating curves with the 10 min discharge data 1983-2012. Only about $10 \%$ of the total export is delivered by discharges lower than $\sim 4000 \mathrm{~L} \mathrm{~s}^{-1}$, which is on average exceeded for less than 6 min $\mathrm{yr}^{-1}$. Thus, large events dominate the signal.

\subsection{Implications for sampling strategies}

Using the rating curve and measured discharge, estimations of CPOM export during individual events and over longer timescales can be calculated. This assumes that the rating curve derived from the data has not changed over the considered period and is representative for the average transport throughout the year (rather than for a specific season). At the Erlenbach, due to the strong dependence of CPOM on discharge with a rating curve exponent of 4.47, CPOM transport is dominated by large discharge events (Fig. 9). For instance, applying the rating curve to the measured discharge in the extreme event in August 2010, this event alone exported nearly $2 \times 10^{6} \mathrm{~kg}$ of CPOM, comprising $94 \%$ of the total export for the year 2010. Without deriving a detailed rating curve, similarly strong dependencies on discharge have been reported previously (e.g., Bormann et al., 1969; Fisher and Likens, 1973; Wallace et al., 1995). The strong dependence of CPOM transport on discharge suggests that measurements conducted at low flows give an incomplete picture of overall CPOM transport. However, if the scaling exponent of the mass distribution is known, and if for a given event a certain size fraction has been sampled representatively, the complete CPOM export can be calculated. Our study results suggest that CPOM export for all size fractions can be estimated from the volumes of LWD exported in a large event, for example by measuring piece sizes trapped in a reservoir or by video monitoring the passage of wood pieces (e.g., MacVicar and Piégay, 2012; MacVicar et al., 2009; Moulin and Piégay, 2004; Seo et al., 2008; West et al., 2011). In addition to 
scaling down from LWD deposits with the aim to estimate total CPOM export, the scaling relations also permit scaling up from measurements of small CPOM to estimate LWD transport. The combination of a rating curve of CPOM transport rates with discharge and the mass distribution obtained from samples collected at low and intermediate flows can be used to discuss the mobility of LWD.

\subsection{Mobility of large woody debris and hazard assessment}

Floating wood is a source of hazard in many mountain streams (e.g., Comiti et al., 2006; Mazzorana et al., 2011; Rickenmann, 1997). For example, woody debris can jam in channel constrictions or at bridges, which may trap sediment and force water to overflow and leave the channel, ultimately causing overbank sedimentation. In this case the arrival frequency of pieces larger than a potentially hazardous size is an important parameter to consider. In addition, logs floating at the surface of the stream can move at high speeds, and can cause considerable damage upon impact on infrastructure elements such as bridge piers. We will here give an example of how the scaling relation and the knowledge of the rating curve can be used to estimate the frequency of arrival of LWD of a minimum weight. Using the definition that LWD pieces have a diameter larger than $0.1 \mathrm{~m}$ and a length larger than $1 \mathrm{~m}$ (Wohl and Jaeger, 2009), and assuming a dry wood density of $410 \mathrm{~kg} \mathrm{~m}^{-3}$ and a cylindrical shape, LWD has a minimum dry mass of $\sim 3.2 \mathrm{~kg}$. As an example, we will use a mass of $3 \mathrm{~kg}$ as the minimum value for the calculation. The values for a different mass limit can easily be calculated using Eq. (3). According to Eq. (3), the mass of all transported pieces heavier than $3 \mathrm{~kg}$ is $1.73 \times 10^{-4}$ times the total load of pieces heavier than $0.1 \mathrm{~g}$. Using the rating curve, the transport rate of LWD and the frequency of piece arrivals can thus be obtained. According to our results, at the Erlenbach a potentially hazardous piece of wood with a mass of $3 \mathrm{~kg}$ or more arrives on average every ten minutes at a discharge of $\sim 3400 \mathrm{~L} \mathrm{~s}^{-1}$, every minute at a discharge of $\sim 5800 \mathrm{~L} \mathrm{~s}^{-1}$, every ten seconds at a discharge of $\sim 8600 \mathrm{~L} \mathrm{~s}^{-1}$ and every second at a discharge of $14400 \mathrm{~L} \mathrm{~s}^{-1}$. The uncertainty of these estimates is dependent on the quality of the original sampling data, the observed range of discharge and mass of pieces, and of the statistical methods used in the analysis. An independent confirmation of our estimates would require additional field efforts and is beyond the scope of the present paper. Nevertheless, calculations similar to the ones made above may help to assess the potential hazard of LWD in floods of certain sizes. Mobility of wood of all sizes may of course be limited by the ready availability of the material in or near the stream.

\subsection{Transferability of the results to other catchments}

We have presented results on the mass distribution of transported material for a single small headwater catchment, the Erlenbach. We hypothesize that a similarly consistent, i.e., discharge-independent scaling relation of transported CPOM masses can be found in other streams, with a scaling exponent that is characteristic for the catchment. Clearly, forest type, vegetation growth rates, and the distribution of forest throughout the catchment should be important, as they determine the type, amount, and sizes of woody debris available for delivery to the channel. All of these parameters are dependent on the climatic regime, which also determines wind speeds, wind direction and the rate of occurrence of extreme precipitation events. These, in turn, determine how often twigs and branches fall into or close to the channel, if trees can be uprooted, and when landslides are triggered. It seems reasonable to expect CPOM supply to vary in time. More material should be available after severe storms, particularly when they occur in the growth season, or in autumn, when broadleaf trees lose their leaves. Once CPOM has entered the channel, hydraulics, and the relative importance of different decay and transport processes in the stream play a role in modifying CPOM particle mass distributions. Finally, we expect the scaling exponent to be a function of the distance of the sampling locations from source regions, and of the drainage area, because channel processes and channelhillslope coupling can change along a stream, and because material will break down in transport.

Transported CPOM is recruited from material stored in or near the stream. The distributions should therefore be related. The mass distribution of transported material could differ from in-stream material because of size-dependent entrainment and transport behavior of different CPOM pieces. In addition, CPOM can have a wide range of different shapes, which can affect particle mobility. Small CPOM pieces can be elongated (twigs, conifer needles), rounded, or platy (wood chips, bark fragments, scales of conifer cones, leaves, see Fig. 2a), while LWD is typically elongated (logs and branches). In addition, twigs and logs may have branches or root wads, which can lower mobility and enhance the likelihood of trapping (e.g., Abbe and Montgomery, 1996; Braudrick and Grant, 2000).

The data collected by Rickli and Bucher (2006) on distributions of in-stream LWD in ten mountainous catchments of Switzerland provides some evidence for the transferability of the Erlenbach observations. We found consistent power-law distributions of frequency per mass class vs. particle mass for all of these streams, indicating that there is some generality in this type of distribution (cf. Fig. 7 and Table 1). Albeit, the scaling exponent for LWD in log jams is smaller than the scaling exponent for all in-stream wood (Table 1). Similarly, for the Erlenbach, the log jam scaling exponent is smaller than for the transported material, implying that coarser material is moved less frequently than smaller material. This 
reflects the selective transport of large pieces of wood and the fact that jamming makes coarse material less mobile. While scaling exponents differ between mobile and stored LWD, the scaling exponents for in-stream wood do not show significant correlation (tested using Kendall's tau rank correlation coefficient and $R^{2}$ from a linear regression) with any of the tested predictor variables: mean elevation above sea level, drainage area, channel bed slope, channel width, and percent forested area (Fig. 8). However, the range of conditions in the investigated streams is small and a final assessment would need a larger database. For example, the channel bed slope of all studied streams is at least $7 \%$, while the maximum drainage area is about $3 \mathrm{~km}^{2}$. In contrast, the percentage of forested area varies between 17 and $65 \%$, covering a fairly large range. The lack of correlation to the scaling exponent may imply that the distribution of forest along the stream is more important in determining the scaling exponent than the percentage of forested area. Typically, forest is denser near the banks of a stream than far from them, due to the ready availability of water, or due to land use management.

Not many reports of size distributions of CPOM can be found in the literature, and the majority of the available studies used piece diameter as descriptor variable (e.g., Harmon et al., 1986; Jackson and Sturm, 2002). We were able to find a single study using volume as a descriptor variable (Hogan, 1987). We digitized the data for the unlogged reaches, and found power law scaling with exponent values of 1.72 for the small watershed $\left(3.9 \mathrm{~km}^{2}\right), 1.61$ for the medium watershed $\left(6.9 \mathrm{~km}^{2}\right)$ and 1.90 for the large watershed $\left(20.2 \mathrm{~km}^{2}\right)$ (here, the depiction of "small", "medium" and "large" is after Hogan's (1987) own terminology). These values are larger than the scaling exponent for log jam material in the Erlenbach, but are comparable to the exponents for in-stream material of the other Swiss streams. MacVicar and Piégay (2012) reported the distribution of LWD piece length in transport, observed using a video camera during floods of the Ain River, France. The Ain River is a much larger stream than the Erlenbach, with a drainage area of $3630 \mathrm{~km}^{2}$ (compared to $0.7 \mathrm{~km}^{2}$ at the Erlenbach) and a width of $\sim 65 \mathrm{~m}$ (compared to $\sim 4 \mathrm{~m}$ at the Erlenbach). In general, LWD pieces longer than the channel width are rarely transported (Bilby and Ward, 1989; Nakamura and Swanson, 1993), and it has been shown in field studies that LWD moves further and more frequently in larger streams (e.g., Lienkamper and Swanson, 1987). Thus, a slightly greater abundance of long pieces in the Ain River in comparison to the Erlenbach may be expected. The observed mass distribution yields a well-defined power-law scaling with a scaling exponent of 1.8 (B. MacVicar, personal communication, 2013), which is similar to the one observed at the Erlenbach (1.84) (see also the discussion version of the paper and the reviewers' comments for more details on the Ain River data).

In summary, we have found similar scaling exponents for in-stream LWD of eleven Swiss mountain streams, including the Erlenbach, and small forested catchments in British
Columbia, Canada (Hogan, 1987). In addition, we found similar scaling exponents for transported LWD in the Erlenbach headwater stream, Switzerland (this study), and the Ain River, France (MacVicar and Piégay, 2012). This suggests that, at least for LWD, piece mass scales as a declining power law with scaling exponents between about 1.4 and 2.0 (cf. Table 1).

\section{Conclusions}

We have demonstrated that the mass of coarse particulate organic matter (CPOM) transported in the Erlenbach, a steep mountain headwater stream in the pre-Alps of Switzerland, displays a well-defined scaling behavior. The scaling is consistent over almost seven orders of magnitude of particle mass and independent of discharge. Such scaling information can be used to make comparable CPOM transport rates collected with different sampling methods and to estimate the total masses of exported material from small samples comprising only a few size classes of CPOM. Currently, our results have been demonstrated to hold fully for the Erlenbach only. However, the comparison of the Erlenbach data with the scaling distributions of large woody debris transported in the Ain River, France, and of in-channel material in ten small Swiss mountain streams and forested catchments in British Columbia, Canada, suggests that a similarly consistent scaling behavior between CPOM masses and the number of pieces exist for other streams. We found that the watershed/channel parameters examined in the eleven Swiss data sets did not determine LWD scaling; however, the number of streams and the ranges of the observed values are too small to make final conclusions. Thus, it remains to be determined in how far the scaling exponent depends on stream type, vegetation, climate, substrate properties, and on the connectivity between channels and hillslopes. High quality data on piece mass of CPOM in streams spanning the full range of masses are rare, and a full evaluation of our findings is not possible at this stage. If a scaling similar to the one observed at the Erlenbach, which consistently holds over nearly seven orders of magnitude in particle mass and three orders of magnitude in discharge, is correct, measurements of scaling exponents on a small fraction of transported or stored material can be used to extrapolate from LWD to total CPOM or vice versa. This may be useful to assess the hazard potential of large woody debris during floods, it may simplify the planning and logistics of measurement campaigns, and it may help in obtaining woody debris budgets for stream reaches.

Acknowledgements. We thank the current and former members of the mountain hydrology team, especially A. Klaiber, A. Ludwig, A. Pöhlmann, and C. Wyss for help in the field. B. Fritschi and D. Rickenmann designed the basket samplers and contributed through discussions. Further discussions with R. Hilton, N. Hovius, J. Kirchner, K. Krause, and P. Schleppi are acknowledged. We 
are grateful to D. Hunziker, A. Klaiber, A. Pöhlmann, C. Schär, and M. Sieber, who spend many hours counting, weighing and measuring pieces of woody debris. A. Beer helped to make Fig. 1. B. MacVicar, H. Piégay, J. Warburton, an anonymous reviewer, and AE M. Krautblatter provided constructive comments on the discussion paper. This study was supported by SNF grants 200021_124634/1 and 200021_137681/1, and WSL.

Edited by: M. Krautblatter

\section{References}

Abbe, T. B. and Montgomery, D. R.: Large woody debris jams, channel hydraulics and habitat formation in large rivers, Regul. River., 12, 201-221, 1996.

Abbe, T. B. and Montgomery, D. R.: Patterns and processes of wood debris accumulation in the Queets river basin, Washington, Geomorphology, 51, 81-107, 2003.

Benda, L. E. and Sias, J. C.: A quantitative framework for evaluating the mass balance of in-stream organic debris, Forest Ecol. Manag., 172, 1-16, 2003.

Bertram, J. E. A.: Size-dependent differential scaling in branches: the mechanical design of trees revisited, Trees, 4, 241-253, 1989.

Bilby, R. E. and Ward, J. W.: Changes in characteristics and function of woody debris with increasing size of streams in western Washington, Trans. Am. Fish. Soc., 118, 368-378, 1989.

Bilby, R. E. and Ward, J. W.: Characteristics and function of large woody debris in streams draining old-growth, clear-cut, and second-growth forests in southwestern Washington, Can. J. Fish. Aquat. Sci., 48, 2499-2508, 1991.

Bormann, F. H., Likens, G. E., and Eaton, J. S.: Biotic regulation of particulate and solution losses from a forest ecosystem, Bioscience, 19, 600-611, 1969.

Braudrick, C. A. and Grant, G. E.: When do logs move in rivers?, Water Resour. Res., 36, 571-583, 2000.

Brooks, A. P., Gehrke, P. C., Jansen, J. D., and Abbe, T. B.: Experimental reintroduction of woody debris on the Williams River, NSW: Geomorphic and ecological responses, River Res. Appl., 20, 513-536, 2004.

Bunte, K., Abt, S. R., Potyondy, J. P., and Ryan, S. E.: Measurement of coarse gravel and cobble transport using portable bedload traps, J. Hydraul. Eng., 130, 879-893, doi:10.1061/(ASCE)07339429(2004)130:9(879), 2004.

Bunte, K., Swingle, K. W., and Abt, S. R.: Guidelines for using bedload traps in coarse-bedded mountain streams: Construction, installation, operation and sample processing, 91 pp., General Technical Report RMRS-GTR-191, U.S. Forest Service, Rocky Mountain Research Station, Fort Collins, Colorado, http://www. fs.fed.us/rm/pubs/rmrs_gtr191.pdf, 2007.

Comiti, F., Andreoli, A., Lenzi, M. A., and Mao, L.: Spatial density and characteristics of woody debris in five mountain rivers of the Dolomites (Italian Alps), Geomorphology, 78, 44-63, doi:10.1016/j.geomorph.2006.01.021, 2006.

Cummins, K. W.: Structure and function of stream ecosystems, BioScience, 24, 631-641, 1974.

Curran, J. C.: Mobility of large woody debris (LWD) jams in a low gradient channel, Geomorphology, 116, 320-329, doi:10.1016/j.geomorph.2009.11.027, 2010.
Dassot, M., Colin, A., Santenoise, P., Fournier, M., and Constant, T.: Terrestrial laser scanning for measuring the solid wood volume, including branches, of adult standing trees in the forest environment, Comput. Electron. Agr., 89, 86-93, doi:10.1016/j.compag.2012.08.005, 2012.

Faustini, J. M. and Jones, J. A.: Influence of large woody debris on channel morphology and dynamics in steep, boulder-rich mountain sreams, western Cascades, Oregon, Geomorphology, 51, 187-205, 2003.

Fisher, S. G. and Likens, G. E.: Stream ecosystem: Organic energy budget, BioScience, 22, 33-35, 1972.

Fisher, S. G. and Likens, G. E.: Energy flow in Bear Brook, New Hampshire: An integrative approach to stream ecosystem metabolism, Ecol. Monogr., 43, 421-439, 1973.

Harmon, M. E., Franklin, J. F., Swanson, F. J., Sollins, P., Gregory, S. V., Lattin, J. D., Anderson, N. H., Cline, S. P., Aumen, N. G., Sedell, J. R., Lienkaemper, G. W., Cromack, K., and Cummins, K. W.: Ecology of coarse woody debris in temperate ecosystems, Adv. Ecol. Res., 15, 132-302, 1986.

Hassan, M. A., Hogan, D. L., Bird, S. A., May, C. L., Gomi, T., and Campbell, D.: Spatial and temporal dynamics of wood in headwater streams of the Pacific Northwest, J. Am. Water Resour. As., 41, 899-919, 2005.

Hegg, C., McArdell, B. W., and Badoux, A.: One hundred years of mountain hydrology in Switzerland by the WSL, Hydrol. Process., 20, 371-376, doi:10.1002/hyp.6055, 2006.

Hogan, D. L.: The influence of large organic debris on channel recovery in the Queen Charlotte Islands, British Columbia, Canada, in: Erosion and Sedimentation in the Pacific Rim (Proceedings of the Corvallis Symposium, August, 1987), IAHS Publ. no. 165, 1987.

Jackson, C. R. and Sturm, C. A.: Woody debris and channel morphology in first- and second-order forested channels in Washington's coast ranges, Water Resour. Res., 38, 1177, doi:10.1029/2001WR001138, 2002.

Keller, E. A. and Swanson, F. J.: Effects of large organic material on channel form and fluvial process, Earth Surf. Process., 4, 361380, 1979.

Kraft, C. E. and Warren, D. R.: Development of spatial pattern in large woody debris and debris dams in streams, Geomorphology, 51, 127-139, 2003.

Lienkaemper, G. W. and Swanson, F. J.: Dynamics of large woody debris in streams in old-growth Douglas-fir forests, Can. J. Forest Res., 17, 150-156, 1987.

MacFarlane, W. A. and Wohl, E.: Influence of step composition on step geometry and flow resistance in step-pool streams of the Washington Cascades, Water Resour. Res., 39, 1037, doi:10.1029/2001WR001238, 2003.

MacVicar, B. and Piégay, H.: Implementation and validation of video monitoring for wood budgeting in a wandering piedmont river, the Ain River (France), Earth Surf. Proc. Land., 37, 12721289, doi:10.1002/esp.3240, 2012.

MacVicar, B., Piégay, H., Henderson, A., Comiti, F., Oberlin, C., and Pecorari, E.: Quantifying the temporal dynamics of wood in large rivers: field trials of wood surveying, dating, tracking, and monitoring techniques, Earth Surf. Proc. Land., 34, 2031-2046, doi:10.1002/esp.1888, 2009.

Manga, M. and Kirchner, J. W.: Stress partitioning in streams by large woody debris, Water Resour. Res., 36, 2373-2379, 2000. 
Mao, L., Andreoli, A., Comiti, F., and Lenzi, M. A.: Geomorphic effects of large wood jams on a sub-antarctic mountain stream, River Res. Appl., 24, 249-266, doi:10.1002/rra.1062, 2008.

Martin, D. J. and Benda, L. E.: Patterns of instream wood recruitment and transport at the watershed scale, Trans. Am. Fish. Soc., 130, 940-958, 2001.

Mazzorana, B., Hübl, J., Zischg, A., and Largiader, A.: Modelling woody material transport and deposition in alpine rivers, Nat. Hazards, 56, 425-449, doi:10.1007/s11069-009-9492-y, 2011.

Merten, E. C., Vaz, P. G., Decker-Fritz, J. A., Finlay, J. C., and Stefan, H. G.: Relative importance of breakage and decay as processes depleting large wood from streams, Geomorphology, 190, 40-47, doi:10.1016/j.geomorph.2013.02.006, 2013.

Minshall, G. W.: Role of allochthonous detritus in the trophic structure of a woodland springbrook community, Ecology, 48, 139149, 1967.

Molnar, P., Densmore, A. L., McArdell, B. W., Turowski, J. M., and Burlando, P.: Analysis of changes in the steppool morphology and channel profile of a steep mountain stream following a large flood, Geomorphology, 124, 85-94, doi:10.1016/j.geomorph.2010.08.014, 2010.

Montemarano, J. J., Kershner, M. W., and Leff, L. G.: Crayfish effects on fine particulate organic matter quality and quantity, Fund. Appl. Limnol. - Archiv für Hydrobiologie, 168, 223-229, doi:10.1127/1863-9135/2007/0169-0223, 2007.

Montgomery, D. R. and Piégay, H.: Wood in rivers: interactions with channel morphology and processes, Geomorphology, 51, 15, 2003.

Moulin, B. and Piégay, H.: Characteristics and temporal variability of large woody debris trapped in a reservoir on the river Rhone (Rhone): Implications for river basin management, River Res. Appl., 20, 79-97, doi:10.1002/rra.724, 2004

Nakamura, F. and Swanson, F. J.: Effects of coarse woody debris on morphology and sediment storage of a mountain stream system in western Oregon, Earth Surf. Proc. Land., 18, 43-61, 1993.

Reeves, G. H., Burnett, K. M., and McGarry, E. V.: Sources of large wood in the main stem of a fourth-order watershed in coastal Oregon, Can. J. Forest Res., 33, 1363-1370, doi:10.1139/x03095, 2003.

Rickenmann, D.: Schwemmholz und Hochwasser, Wasser, Energie, Luft, 89, 115-119, 1997.

Rickenmann, D., Turowski, J. M., Fritschi, B., Klaiber, A., and Ludwig, A.: Bedload transport measurements at the Erlenbach stream with geophones and automated basket samplers, Earth Surf. Proc. Land., 37, 1000-1011, doi:10.1002/esp.3225, 2012.

Rickli, C. and Bucher, H.: Einfluss ufernaher Bestockung auf das Schwemmholzvorkommen in Wildbächen, technical report, Swiss Federal Research Institute WSL, 94 pp., www.wsl.ch/fe/gebirgshydrologie/wildbaeche/projekte/ schwemmholzvorkommen/rickli_shber_261007.pdf, 2006.
Schleppi, P., Muller, N., Edwards, P. J., und Bucher, J. B.: Three years of increased nitrogen deposition do not affect the vegetation of a montane forest ecosystem, Phyton, 39, 197-204, 1999.

Schuerch, P., Densmore, A. L., McArdell, B. W., and Molnar, P.: The influence of landsliding on sediment supply and channel change in a steep mountain catchment, Geomorphology, 78, 222235, doi:10.1016/j.geomorph.2006.01.025, 2006.

Seo, J. I., Nakamura, F., Nakano, D., Ichiyanagi, H., and Chun, K. W.: Factors controlling the fluvial export of large woody debris, and its contribution to organic carbon at watershed scales, Water Resour. Res., 44, W04428, doi:10.1029/2007WR006453, 2008.

Turowski, J. M., Yager, E. M., Badoux, A., Rickenmann, D., and Molnar, P.: The impact of exceptional events on erosion, bedload transport and channel stability in a step-pool channel, Earth Surf. Proc. Land., 34, 1661-1673, doi:10.1002/esp.1855, 2009.

Turowski, J. M., Badoux, A., and Rickenmann, D.: Start and end of bedload transport in gravel-bed streams, Geophys. Res. Lett., 38, L04401, doi:10.1029/2010GL046558, 2011.

Turowski, J. M., Badoux, A., Leuzinger, J., and Hegglin, R.: Large floods, alluvial overprint and bedrock erosion, Earth Surf. Proc. Land., 38, 947-958, doi:10.1002/esp.3341, 2013.

Wallace, J. B., Whiles, M. R., Eggert, S., Cuffney, T. F., Lugthart, G. J., and Chung, K.: Long-term dynamics of coarse particulate organic matter in three Appalachian mountain streams, J. N. Am. Bent. Soc., 14, 217-232, 1995.

Webster, J. R. and Benfield, E. F.: Vascular plant breakdown in freshwater ecosystems, Annu. Rev. Ecol. Evol. Syst., 17, 567594, 1986.

Webster, J. R. and Meyer, J. L.: Organic matter budgets for streams: A synthesis, J. N. Am. Benthol. Soc., 16, 141-161, 1997.

Webster, J. R., Benfield, E. F., Ehrman, T. P., Schaeffer, M. A., Tank, J. L., Hutchens, J. J., and D'Angelo, D. J.: What happens to allochthonous material that falls into streams? A synthesis of new and published information from Coweeta, Freshwater Biol., 41, 687-705, 1999.

West, A. J., Lin, C.-W., Lin, T.-C., Hilton, R. G., Liu, S.-H., Chang, C.-T., Lin, K.-C., Galy, A., Sparkes, R. B., and Hovius, N.: Mobilization and transport of coarse woody debris to the oceans triggered by an extreme tropical storm, Limnol. Oceanogr., 56, 77-85, doi:10.4319/1o.2011.56.1.0077, 2011.

Wohl, E. and Jaeger, K.: A conceptual model for the longitudinal distribution of wood in mountain streams, Earth Surf. Proc. Land., 34, 329-344, doi:10.1002/esp.1722, 2009.

Yoshimura, C., Fujii, M., Omura, T., and Tockner, K.: Instream release of dissolved organic matter from coarse and fine particulate organic matter of different origins, Biochemistry, 100, 151-165, doi:10.1007/s10533-010-9412-y, 2010. 